\title{
Creep and Rupture of Dental Amalgam under Bending Stress
}

\author{
Hideo OGURA*, Yukio MIYAGAWA** and Kengo NAKAMURA** \\ *Junior College at Niigata and **Department of Dental Materials Science, School of Dentistry at Niigata \\ The Nippon Dental University, 1-8 Hamauracho, Niigata 951, Japan
}

The bending creep of six different dental amalgams was continuously measured up to 30 days under different static loads. All six amalgams induced creep rupture within 30 days under $9 \mathrm{kgf}$ of static load and some of them did under the lower static load. The high copper amalgams resisted for a longer period of time compared to the low copper amalgams. The admixed high copper amalgam had the highest creep value at rupture under the same load, which indicates that this amalgam is more flexible under continuous loading than the other amalgams. The rupture time was approximately proportional to the reciprocal of the creep rates and the rupture time drastically increased as the creep rate decreased. This result basically explains and supports the previously reported correlation between the compressive creep during a specific period of time and the marginal fracture of amalgam restorations.

Key words: Dental Amalgam, Creep, Bending Test

\section{INTRODUCTION}

It has been shown by several studies ${ }^{1-3)}$ that the compressive creep of dental amalgams significantly correlates with the marginal integrity of amalgam restorations. Although these studies have yielded information useful in the dental practice, the interpretation of the correlation has not been clarified. This could partly be due to the lack of the detailed investigation about the long term creep behavior of dental amalgams.

The purpose of the present study was to investigate the creep behavior of dental amalgams for a long period of time, using a three-point bending test which would induce creep rupture more easily than a compressive test.

\section{MATERIALS AND METHODS}

Six amalgam alloys were used to prepare the rectangular specimens for bending creep test. The type of the alloys and their codes are listed in Table 1. Each alloy was triturated with mercury using an amalgam mixer ${ }^{*}$ which had two levels of mixing speed. A higher mixing speed was employed for all alloys except SY. The trituration time for each alloy was increased by $50 \%$ over the manufacturer's instruction since the alloy for one mix was $2-3$ times heavier than that used ordinarily. The trituration time, the weight of the alloy and the alloy to mercury ratio are shown in Table 2 .

The rectangular specimen was prepared from triturated mix using a stainless split mold (Fig. 1) and a static load. The mix was placed in the mold cavity and $24 \mathrm{kgf}$ of static load $\left(178 \mathrm{kgf} / \mathrm{cm}^{2}\right)$ was applied to the mix $30 \mathrm{~s}$ after the trituration through the rectangular

\footnotetext{
" GC Himix VS II, GC Dental Corp., Tokyo, Japan
} 
Table 1 Amalgam alloys investigated

\begin{tabular}{c|l}
\hline Code & \multicolumn{1}{c}{ Type } \\
\hline L L L $^{* 1}$ & low copper, lathe cut \\
S S*2 & low copper, spherical \\
D P P & high copper, admixed \\
I N N & high copper, single composition \\
T Y & high copper, single composition \\
S Y & high copper, single composition \\
\hline
\end{tabular}

Table 2 Alloy weight, alloy/mercury ratio and trituration time

\begin{tabular}{c|c|c|c}
\hline Code & Alloy (gram) & Alloy/Mercury & $\begin{array}{c}\text { Trituration } \\
\text { Time (sec) }\end{array}$ \\
\hline L L & 1.5 & $1: 1.2$ & 15 \\
S S & 1.8 & $1: 0.84$ & 15 \\
D P & 1.7 & $1 \vdots 1$ & 15 \\
I N & 1.8 & $1: 0.84$ & 15 \\
T Y & 1.8 & $1: 0.82$ & 9 \\
S Y & 1.7 & $15^{*}$ \\
\hline
\end{tabular}

* triturated by low speed

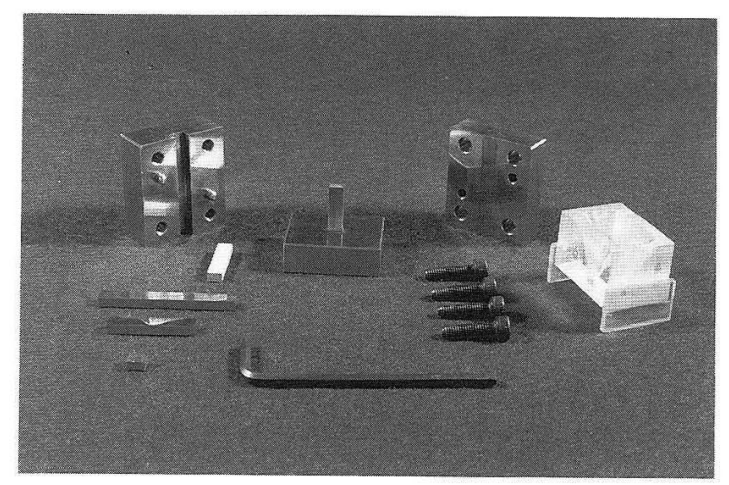

Fig. 1 Split mold assembly.

plunger which had the same sectional dimensions $(3.0 \times 4.5 \mathrm{~mm})$ as the mold cavity. The load was removed $60 \mathrm{~s}$ after the application and the mix was formed into the rectangular shape that was $4.5 \mathrm{~mm}$ wide, $3 \mathrm{~mm}$ thick and about $21-23 \mathrm{~mm}$ long. In order to adjust the specimen length to $20 \mathrm{~mm}$, the plunger was altered to another plunger fixed on a rectangular base, and the excess amalgam was cut off using a thin blade.

The prepared specimen was then stored at $37^{\circ} \mathrm{C}$ in air for 7 days and tested in the

${ }^{* 1}$ GC Luna, GC Dental Industrial Corp., Tokyo, Japan

*2 Shofu Spherical, Shofu Dental Mfg. Co., Ltd., Kyoto, Japan

${ }^{* 3}$ Dispersalloy, Johnson and Johnson Dental Products Co., East Windsor, NJ, USA

${ }^{* 4}$ Indiloy, Shofu Dental Mfg. Co., Ltd., Kyoto, Japan

${ }^{* 5}$ Tytin, S. S. White Dental Products International, Philadelphia, PA, USA

${ }^{* 6}$ Sybraloy, Kerr/Sybron Corp., Romulus, MI, USA 


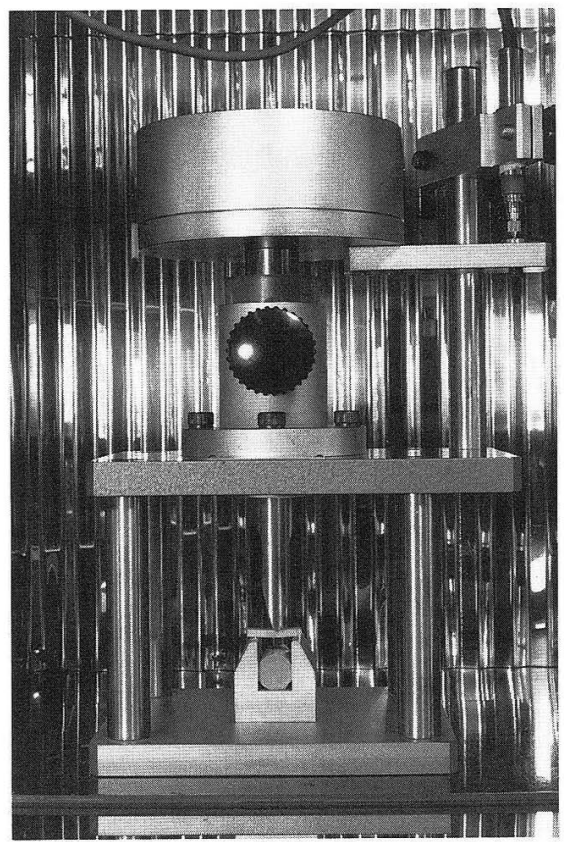

Fig. 2 Three-point bending apparatus with electric micrometer.

three-point bending apparatus which was placed in a chamber at $37^{\circ} \mathrm{C}$ (Fig. 2). The distance between the two supports of the apparatus was $15 \mathrm{~mm}$. The test was performed under 3,5 , 7 or $9 \mathrm{kgf}$ of static load $\left(167,278,389\right.$ or $\left.500 \mathrm{kgf} / \mathrm{cm}^{2}\right)$.

The bending creep, which was the transverse deflection of a specimen, was measured by means of an electric micrometer attached to the loading axis of the bending apparatus and continuously recorded on a chart either for 30 days or till the specimen fractured. The bending creep values at 700 hours were obtained from the charts of the sepcimens which did not rupture during the 30 days. From the charts of the ruptured specimens, the creep values at rupture and the rupture time were obtained. In addition, the creep rates of the whole period until the rupture, the transient state, the steady state and the accelerating state were calculated from each chart by the following equations.

Total Creep Rate (creep rate of whole period) : $R=C / T$

Transient Creep Rate (transient state creep rate) : $R t=C t / T t$

Steady Creep Rate (steady state creep rate) : $R s=C s / T s$

Accelerating Creep Rate (accelerating state creep rate) : $R a=C a / T a$

where, $C$ : creep value at rupture

$T$ : rupture time

$C t$ : transient state creep value

$T t:$ transient state time

Cs : steady state creep value

Ts : steady state time

$C a$ : accelerating state creep value 
$T a$ : accelerating state creep value

The relationship between the calculated creep rates and the rupture time was statistically analyzed.

Two replications were made for each combination of the alloy and the static load, and a total of 48 charts was collected.

\section{RESULTS}

The change in bending creep with time is shown in Figs. 3-8 for each amalgam under different static loads. Each curve is the average of two replications. All amalgams induced

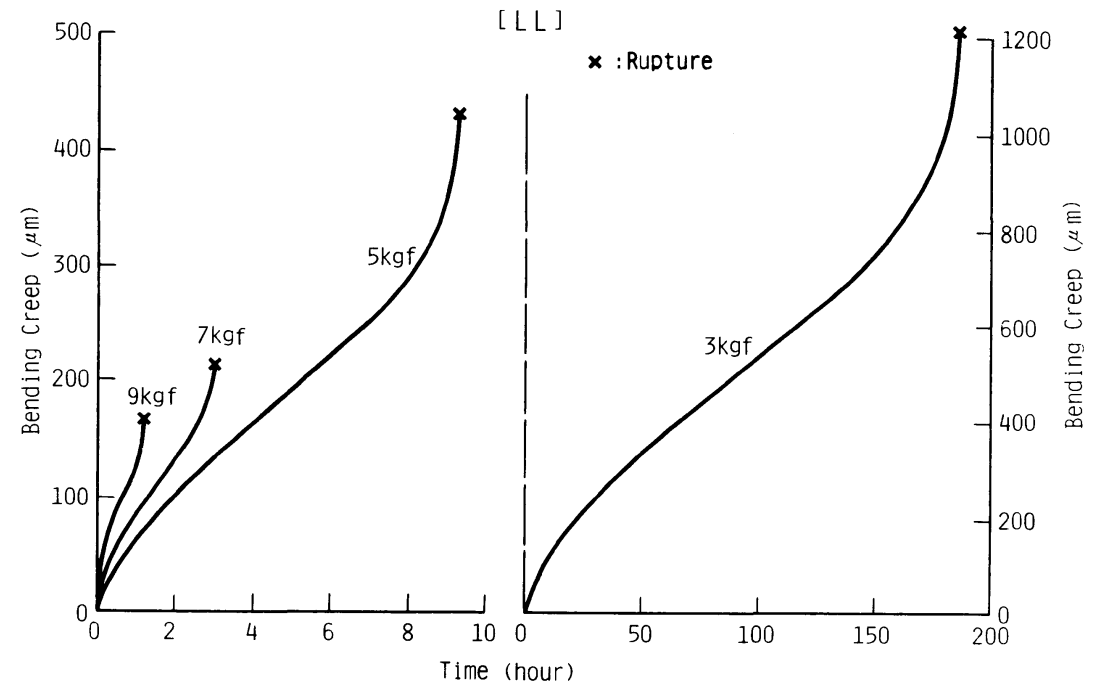

Fig. 3 Bending creep curve of LL amalgam.

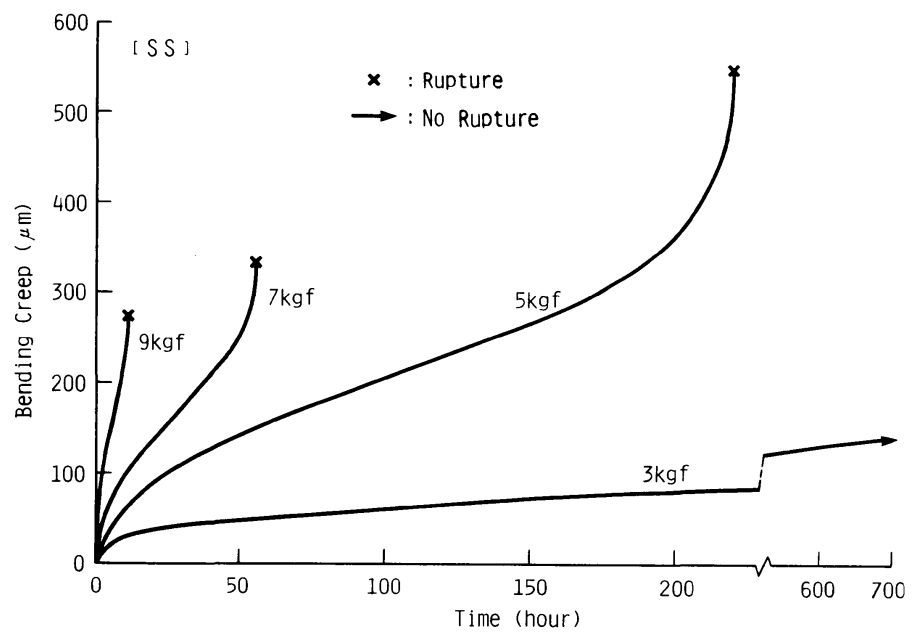

Fig. 4 Bending creep curve of SS amalgam. 


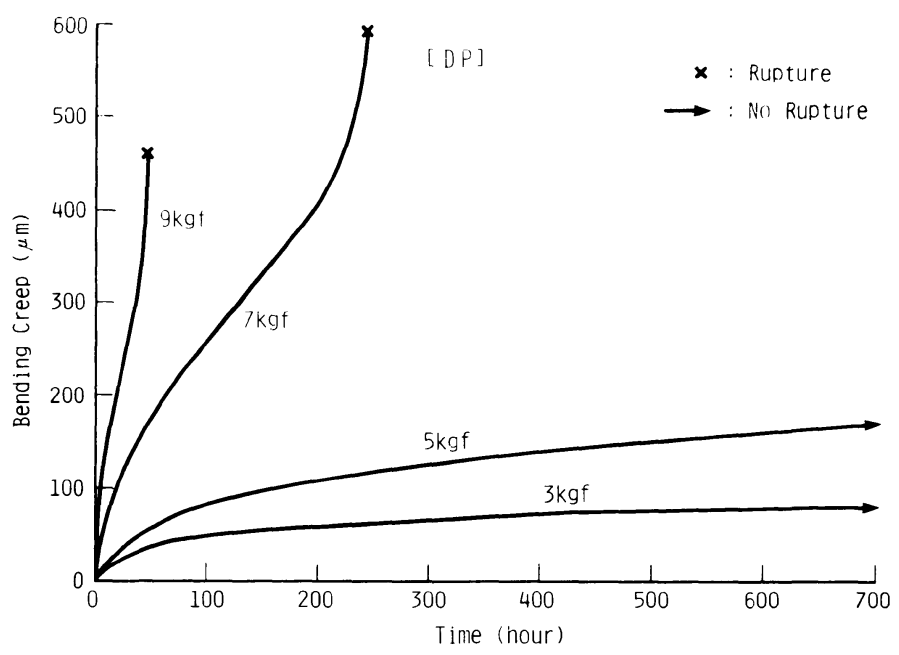

Fig. 5 Bending creep curve of DP amalgam.

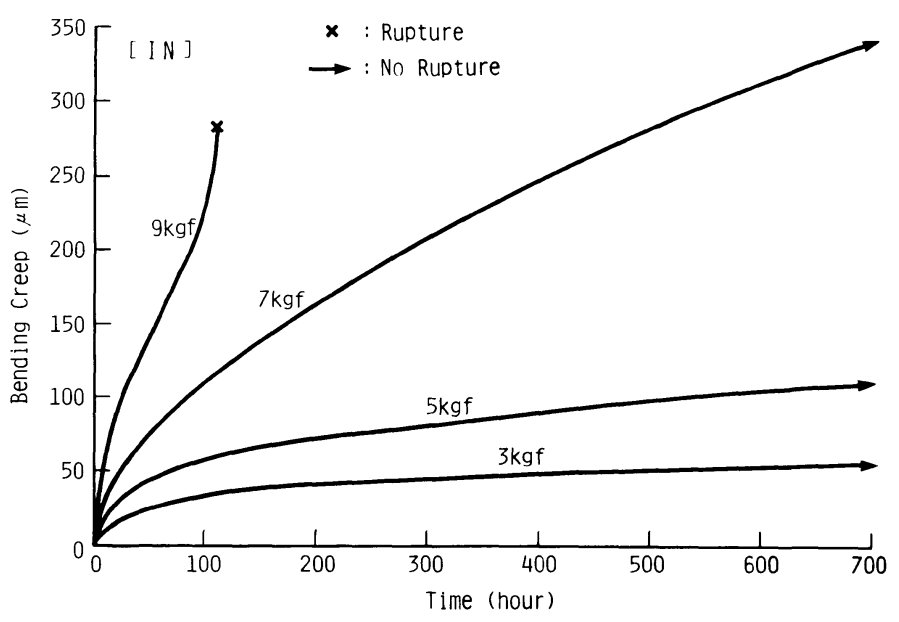

Fig. 6 Bending creep curve of IN amalgam.

creep rupture within 30 days under $9 \mathrm{kgf}$ of static load. These amalgams had a typical creep-time curve as shown in these figures. The low copper lathe-cut amalgam (LL) induced creep rupture within 30 days under all tested loads. On the other hand, creep rupture was not induced 30 days for the three high copper amalgams (IN, TY and SY) consisting of single composition particles under 3, 5 and $7 \mathrm{kgf}$, the high copper admixed amalgam (DP) under 3 and $5 \mathrm{kgf}$, and the low copper spherical amalgam (SS) under $3 \mathrm{kgf}$. For these amalgams, the creep values at 700 hours are summarized in Fig. 9.

For the amalgams which resulted in creep rupture within 30 days, the creep value at rupture and the rupture time are shown in Figs. 10 and 11, respectively. Under $9 \mathrm{kgf}$ of static load, the high copper admixed amalgam (DP) had the highest creep value at rupture and the three high copper single composition amalgams (IN, TY and SY) had longer rupture times 


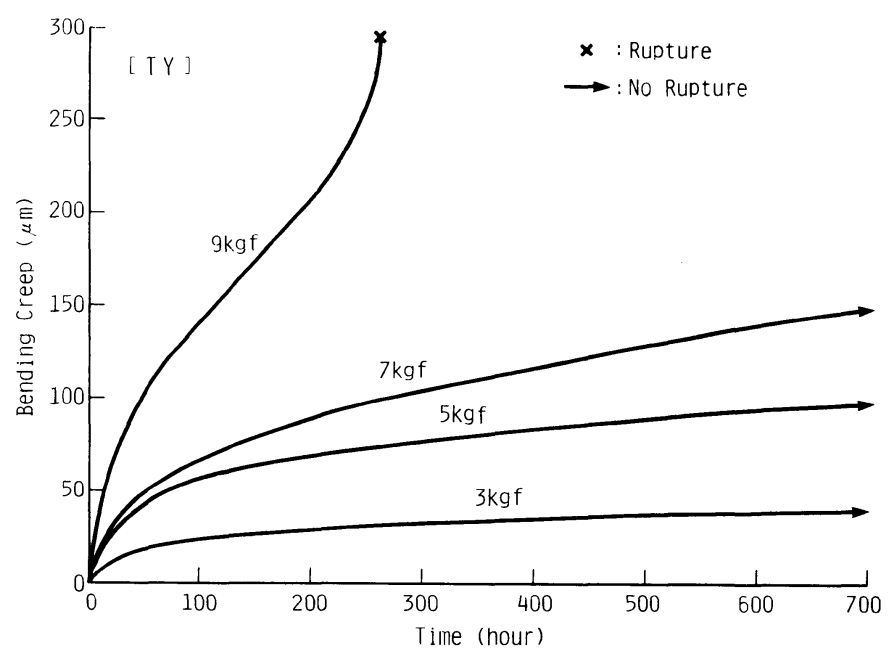

Fig. 7 Bending creep curve of TY amalgam.

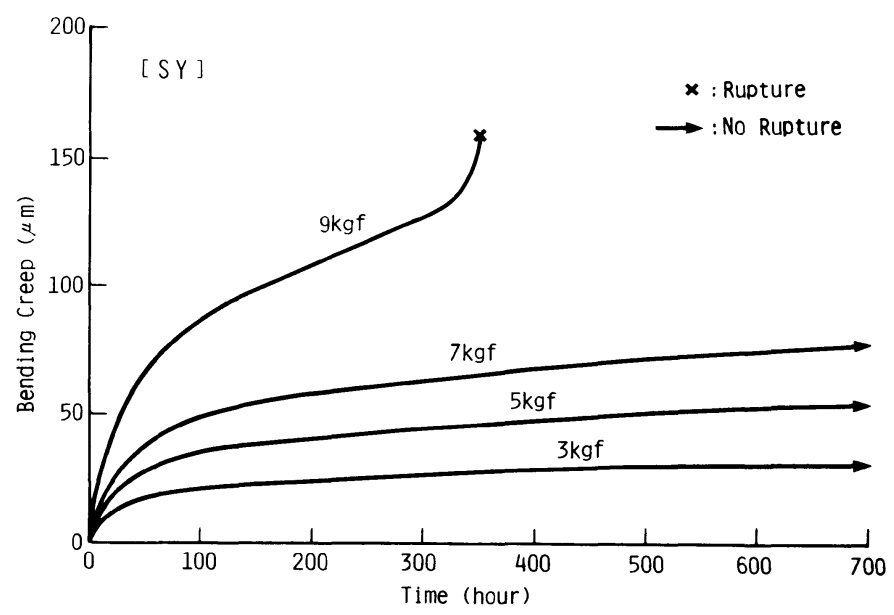

Fig. 8 Bending creep curve of SY amalgam.

than the others as shown in Figs. 10 and 11, respectively. The relationship between the rupture time and each creep rate under $9 \mathrm{kgf}$ is shown in Figs. 12-15. The correlation between the logarithm of the rupture time and the logarithm of each creep rate was highly significant. The regression equations obtained by means of the method of least squares were also highly significant and expressed as :

$$
\log C R=B-A \log T
$$

where $C R$ : Creep Rate either of $R, R t, R s$ or $R a$

$T$ : Rupture Time

$A$ and $B$ : constant

The calculated values of $A$ and $B$ for each creep rate were:

$A=0.954, B=2.330$ for the Total Creep Rate 


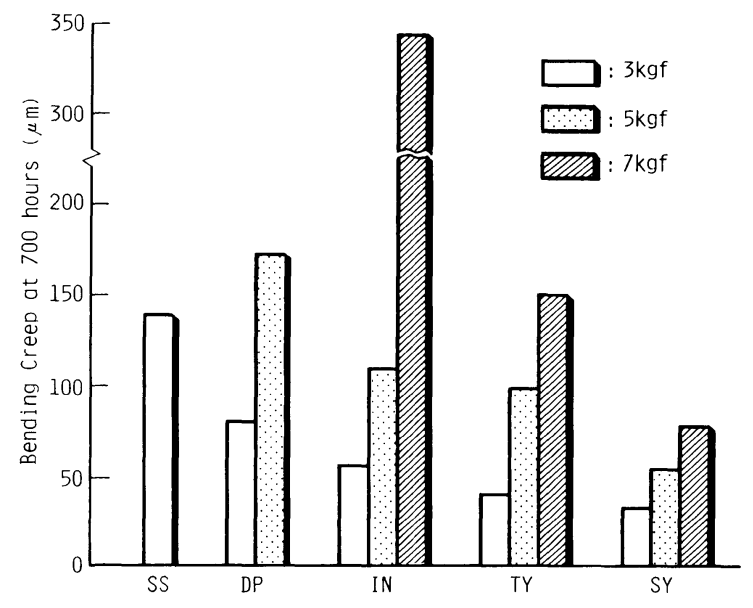

Fig. 9 Bending creep at 700 hours.

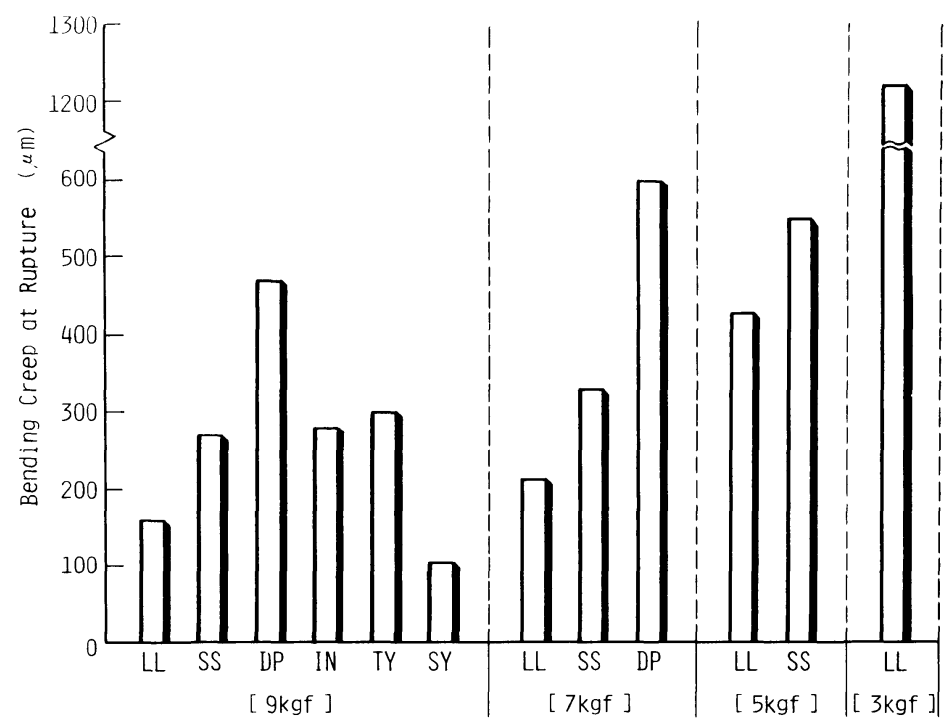

Fig. 10 Bending creep at rupture.

$A=0.917, B=2.408$ for the Transient Creep Rate

$A=1.018, B=2.210$ for the Steady Creep Rate $A=0.877, B=2.345$ for the Accelerating Creep Rate

The equation (1) could be mathematically transformed into the following form :

$$
T=b / \mathrm{CR}^{\mathrm{a}} \cdots \cdots \cdot(2)
$$

where, $T$ : Rupture Time

$C R$ : Creep Rate either of $R, R t, R s$ or $R a$

$a$ and $b$ : constant

The constants, $a$ and $b$ were calculated for each creep rate and their values were : $a=1.048, b=276.9$ for the Total Creep Rate 


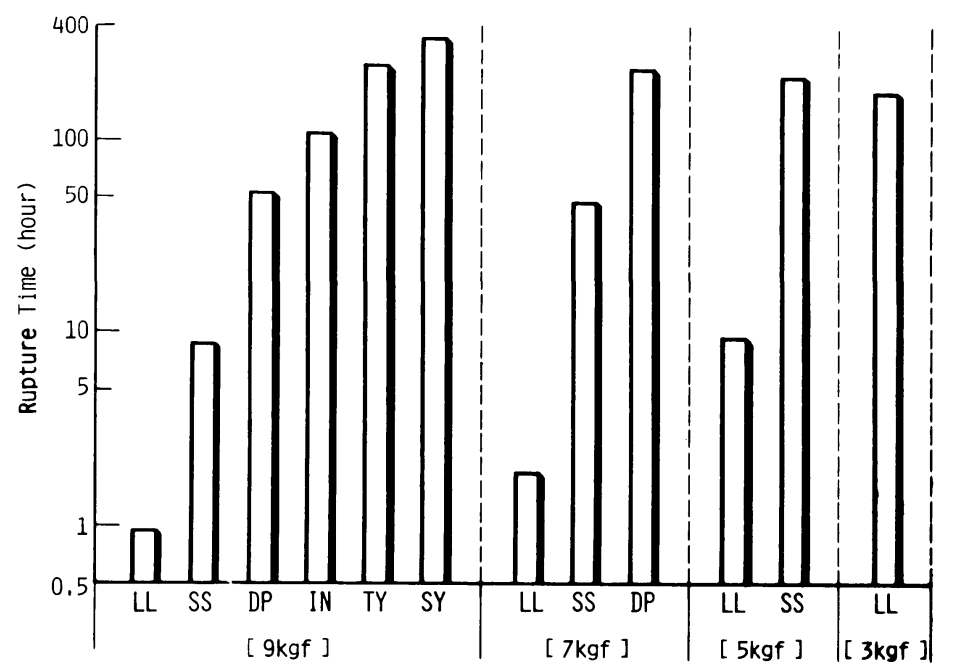

Fig. 11 Rupture time under different static loads.

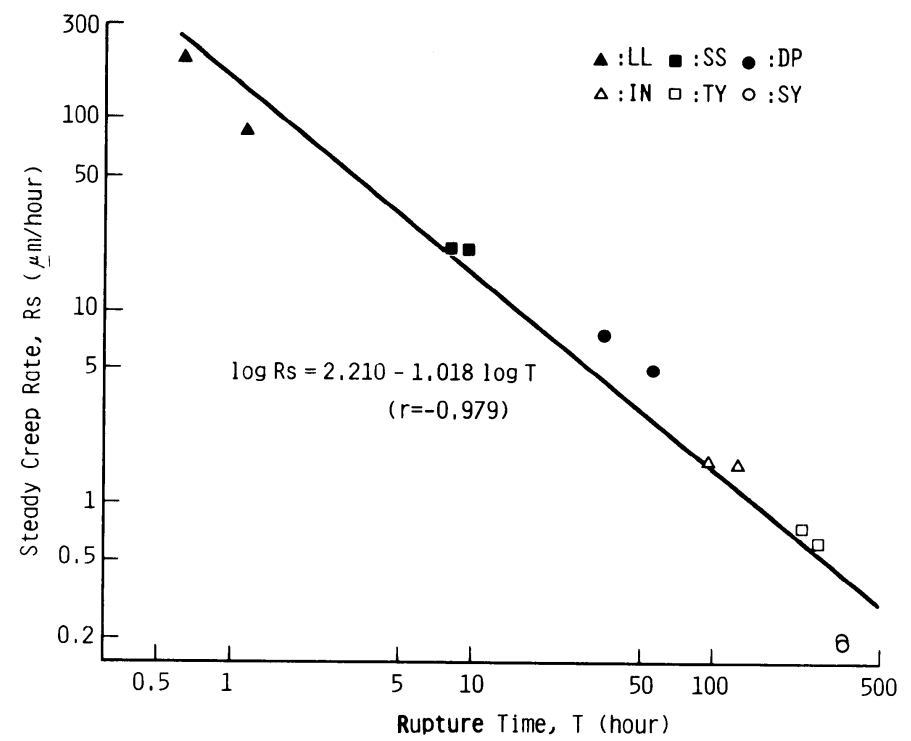

Fig. 12 Relationship between total creep rate and rupture time.

$a=1.091, b=422.7$ for the Transient Creep Rate

$a=0.982, b=148.2$ for the Steady Creep Rate

$a=1.140, b=471.9$ for the Accelerating Creep Rate

The constant $a$, which was a multiplier in the equation, was almost one for each creep rate and the constant $b$ varied with different creep rates. Therefore, the equation (2) could be approximately simplified as :

$$
T=b / C R \cdots \cdots \cdots(3)
$$




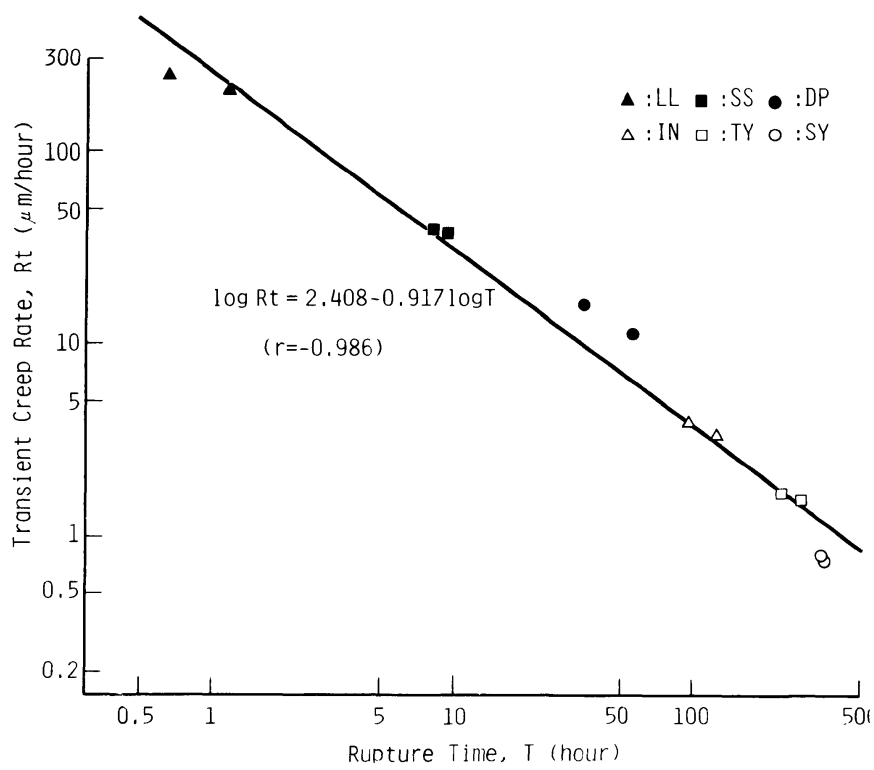

Fig. 13 Relationship between transient creep rate and rupture time.

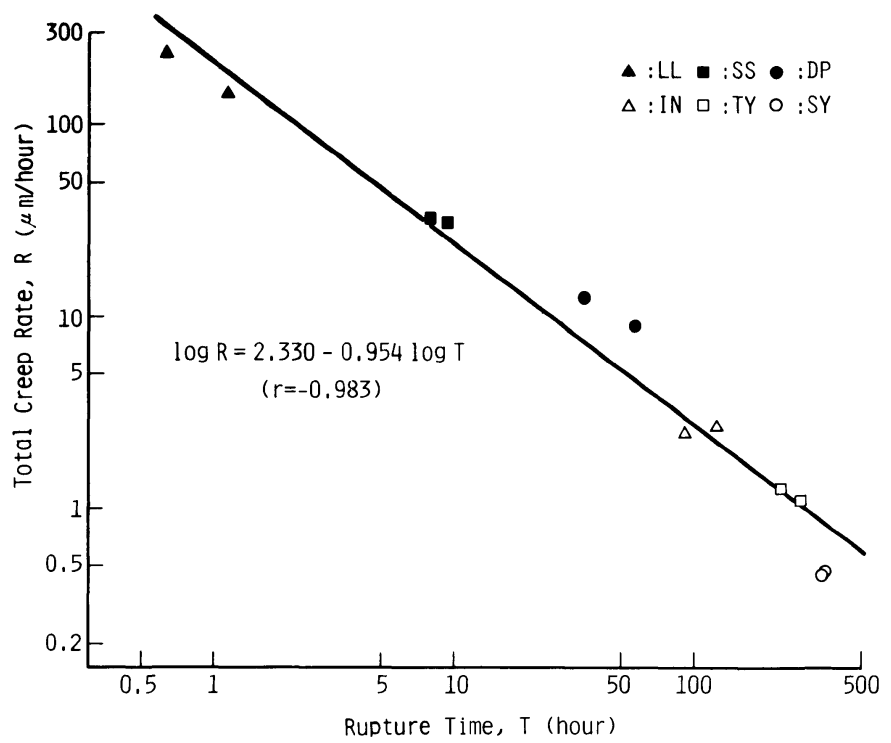

Fig. 14 Relationship between steady creep rate and rupture time.

\section{DISCUSSION}

The low copper spherical amalgam (SS) had the highest bending creep at 700 hours under $3 \mathrm{kgf}$ of static load, followed by the high copper admixed amalgam (DP) and the high copper single composition amalgams (IN, TY and SY) successively, as shown in Fig. 9. This is consistent with the results from a compressive creep test reported by several studies ${ }^{2-4)}$. 


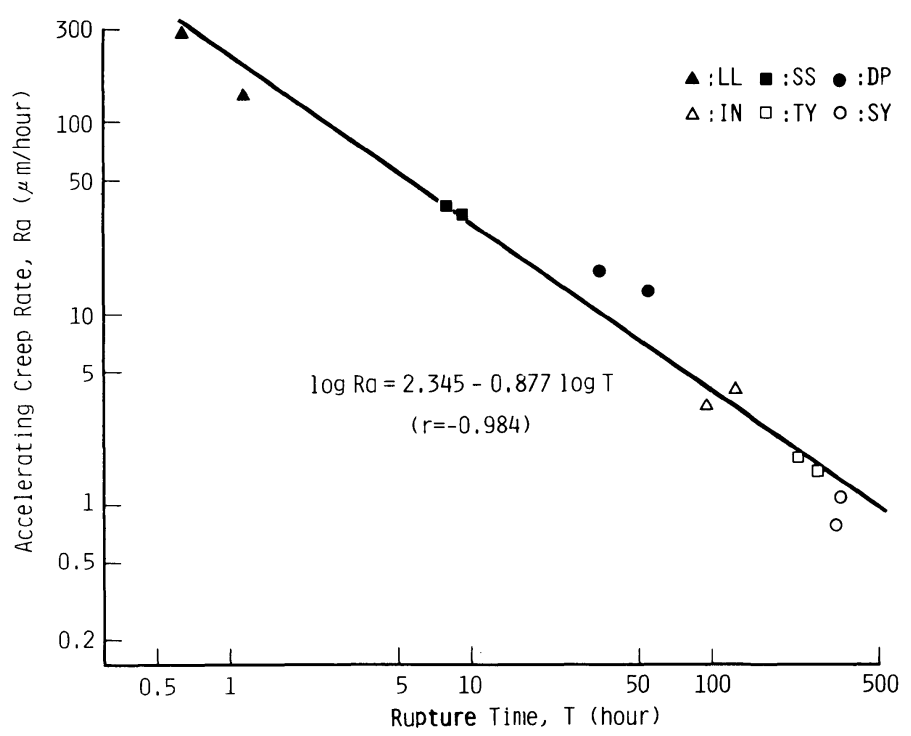

Fig. 15 Relationship between accelerating creep rate and rupture time.

Although a compressive test is a convenient way to measure the creep rate of dental amalgams, the creep rupture would hardly be obtainable in a short period of time. In this study the three-point bending test enabled to induce creep rupture within 30 days and measure the rupture time as well as the creep value at rupture for all amalgams tested.

The high copper admixed amalgam (DP) had the highest creep value at rupture under 7 and $9 \mathrm{kgf}$ of static loads as shown in Fig. 10. This result indicates that the high copper admixed amalgam (DP) is more flexible under a continuous loading than the other amalgams tested. The higher creep value at rupture might be related to the clinical longevity of amalgam restorations. The creep deformation, if it occurs on an amalgam restoration as a result of a long period of loading time accumulated by repeated mastication, could reduce the stress concentration of the occlusal force on the surface, especially at the marginal portion of the restoration. In other words, a higher creep value at rupture could create less stress concentration on the surface of an amalgam restoration, and thus the amalgam restoration would be more resistant to the marginal fracture. It has been shown by clinical evaluations ${ }^{5,6)}$ that the high copper admixed amalgam (DP) has similar or even less marginal fracture compared to the high copper single composition amalgams (IN, TY and SY) that have higher compressive strength and lower creep rate. This clinical result might be partly explained by the aforementioned hypothesis.

It is well-known for many alloys for industrial use that the rupture time is approximately proportional to the reciprocal of the creep rate. In the present study, this relation was also proved for dental amalgams which mainly consisted of intermetallic compounds. Either of the obtained equation (1), (2) or (3) indicates that the creep rupture of dental amalgams could be highly dependent on the creep rate and the effect of the creep rate on the rupture time would be very critical. In addition, the rupture time of a dental amalgam could be roughly estimated from any of the four creep rates (Total Creep Rate, Transient Creep Rate, Steady 
Creep Rate and Accelerating Creep Rate) using the regression equations. From a practical point of view, the transient creep rate would be most convenient to estimate the rupture time in a relatively short time.

As discussed above, the rupture time drastically increased with a decrease in creep rates, which indicates that a lower creep rate could create higher resistance to the creep rupture. This result basically explains and supports the reported correlation between the compressive creep during a specific period of time and the marginal fracture of amalgam restorations ${ }^{1-3}$. The marginal fracture, however, could not be explained only by the creep behavior, since no correlation or adverse correlation has been reported among several high copper amalgams ${ }^{5,6}$. Therefore, the other factors such as the corrosion and toughness of dental amalgams should further be investigated.

\section{CONCLUSIONS}

The long term creep behavior of six different dental amalgams was investigated using a continuous measurement of the bending creep up to 30 days under 3, 5, 7 and $9 \mathrm{kgf}$ static loads $\left(167,278,389\right.$ and $500 \mathrm{kgf} / \mathrm{cm}^{2}$ respectively). Based on the obtained results the following conclusions were drawn.

The high copper amalgams resisted for a longer period of time compared to the low copper amalgams tested. The admixed high copper amalgam had the highest creep value at rupture, which indicates that this amalgam is more flexible under a continuous loading than the other amalgams. The correlations between the four creep rates (Total Creep Rate, Transient Creep Rate, Steady Creep Rate and Accelerating Creep Rate) and the rupture time were highly significant. The rupture time was approximately proportional to the reciprocal of each creep rate and drastically prolonged as the creep rate decreased. This result basically explains and supports the previously reported correlation between the compressive creep during a specific period of time and the marginal fracture of amalgam restorations.

\section{REFERENCES}

1) Mahler, D. B., Terkla, L. G., Van Eisden, J. and Reisbick, M. H. : Marginal fracture vs. mechanical properties of amalgam, J Dent Res 49 : 1452-1457, 1970.

2) Mahler, D. B., Terkla, L. G. and Van Eisden, J. : Marginal fracture of amalgam restorations, $J$ Dent Res 52 : 823-827, 1973.

3) Osborne, J. W., Gale, E. N., Chew, C. L., Rodes, B. F. and Phillips, R. W. : Clinical performance and physical properties of twelve amalgam alloys, J Dent Res $57: 983-988,1978$.

4) Yoshida, T., Ogura, H., Miyasaka, T., Okamura, H. and Sumii, T.: The test of high copper amalgams, DE $58: 8-18,1981$. (in Japanese)

5) Osborne, J. W., Leinfelder, K. F., Gale, E. N. and Sluder, T. B. : Two independent evaluations of ten amalgam alloys, $J$ Prosthet Dent $43: 622-626,1980$.

6) Osborne, J. W., Schlissel, E. R. and Gale, E. N.: Clinical test for the development of new amalgam alloys, J Dent Res 60 : 999, 1981. 
分子鎖の運動性に依存しており，鎖長の短い Bis-MEPP -MPPP や Bis- $\mathrm{ME}_{2.6} \mathrm{PP}$ に比べ,脆性に富む傾向が認め をぺースモノマーとしたコンポジットレジンはBis られた。

\section{歯科用銀基合金の腐食と変色 (第 1 報) 電気化学的腐食試験}

\section{遠藤一彦, 荒木吉馬, 大野弘機 \\ 東日本学園大学歯学部歯科理工学講座}

3 種の市販銀合金, $\mathrm{Ag}-\mathrm{Sn}-\mathrm{Zn}, \mathrm{Ag}-\mathrm{In}$ および $\mathrm{Ag}-\mathrm{Pd}$ - $\mathrm{Cu}$ 合金の腐食挙動を $0.1 \%$ 硫化ナトリウム溶液とリン タ゚ル液中で, 電気化学的手法を用いて調べた。

$\mathrm{Ag}-\mathrm{Sn}-\mathrm{Zn}$ 合金は，0.1\%硫化ナトリウム溶液中より もリンゲル液中において腐食するのに対し, $\mathrm{Ag}-\mathrm{Pd}-\mathrm{Cu}$ 合金は逆に, リンゲル液中ではほとんど腐食しないが, $0.1 \%$ 硫化ナトリウム溶液中において著しく腐食した。 $\mathrm{Ag}-\mathrm{In}$ 合金は $0.1 \%$ 硫化ナトリウム溶液およびリンゲル 液中で同程度に腐食した。

特に, $\mathrm{Ag}-\mathrm{Pd}-\mathrm{Cu}$ 合金は, $0.1 \%$ 硫化ナトリウム溶液中
における腐食速度がリンゲル液中の約 500 倍にも達し， 硫化物イオンあるいは硫化水素イオンを含む溶液中で, 表面が単に変色するのみならず, 腐食により著しく劣化 することが明らかとなった。

歯科用銀基合金は, その成分・組成により腐食に影響 するイオン種が異なる。したがって, 腐食試験を行なう 際には，個々の合金系にお゙いて，口腔内で起こると考え られる重要な腐食反応を充分に検討した上で, 最適な腐 食液を選定する必要がある。

\section{$\mathrm{MKG}$ による鈎歯の挙動の分析}

第 2 報, 片側遊離端義歯におけるクラスプ・デザインの影響

守川雅雄*, 鱒見進一*, 城戸寛史 ${ }^{*}$, 豊田静夫*, 小園凱夫**

*九州歯科大学歯科第 1 補経学講座

**九州歯科大学歯科理工学講座

片側遊離端義歯の維持装置として, RPA, RPI, および Akerの三種類のクラスプをシミュレーション・モデル 上に設定し, 鈎歯の三次元的動的挙動をマンディブラー キネジオグラフ $(\mathrm{MKG})$ を用いて分析し, 比較検討した。 義歯床の第二小臼歯および第二大臼歯相当部に種々の 荷重を加えることによって, 鈎歯はその霜根を回転中心 とした傾斜的挙動を示したが, Aker デザインのものが
最も著しく，遠心煩側への傾斜が認められた。RPAも概 略的にみてAkerの場合と類似した傾向を示した。RPI においては, 鈎蒾を遠心に牽引する傾向が最も少なかっ た。歯牙は側方的な力に対して耐性が極めて小さいとい う構造的な特徵から考えて, RPI のこの性質は, 鈎歯々 周組織保護の観点から今回の三種類の維持装置のうちで は最良のクラスプであろうと考えられた。

\section{歯科用アマルガムの曲げクリープとクリープ破壊 \\ 小倉英夫*, 宮川行男**, 中村健吾** \\ *日本歯科大学新潟短期大学 \\ **日本歯科大学新潟歯学部歯科理工学教室}

6 種の歯科用アマルガムの曲げクリープを異なる静荷 重下で最長 30 日間連続的に測定した。その結果, 試験し た 6 種のアマルガムは 30 日以内のうちに $9 \mathrm{kgf}$ の静荷
重下ですべてクリープ破壞を起こした。また，これより 低い荷重下でもいくつかのアマルガムはクリープ破壊を 起こした。高銅アマルガムは, 従来型の低銅アマルガム 
に比ベクリープ破壊に対し長期間抵抗した。混合型高銅 アマルガムは，破壊時のクリープ值が試験したアマルガ ム中でもっとも大きかった。これはこのアマルガムが 連続的な荷重に対し他のアマルガムに比べてより柔軟性 があるということを意味している。破壊時間はクリープ
速度の逆数にほぼ比例し，クリープ速度が減少すると破 壊時間は急激に増加した。この結果は，以前に報告され た一定期間内のクリープ值とアマルガム修復物の辺縁破 折との相関をクリープ破壊の面から説明し，裏付けてい る。

\section{象牙質処理剂がレジンの接着性に与える影響について}

千葉幹男，伊藤和雄，和久本貞雄

昭和大学歯学部第二歯科保存学教室

Dentin cleanserによって象牙質の受ける変化が接着 性にいかなる影響を及ぼすかについて，リン酸，グリシ ン含有ピルビン酸, EDTAによる歯面清掃を行なった後 の象牙質の物理的特性を計測し，これらとレジンとの接 着性の相関を検討した。その結果，レジンと象牙質との 接着性は, cleanserによって象牙質に与える変化のうち Micro Vickers Hardness の低下と最も高い相関を示し
た。すなわち, cleanserによって残存象牙質硬さが $85 \%$ 以上に保たれるEDTA-2Naによる処理が最も良好な 接着性を示した。このことから，良好な接着性を得るた めには smear layerのみを除去し，象牙質には全く影響 を及ぼさない cleanserが理想的な材料であると結論付 けられた。

\section{Self Etching Dentin Primer の効果}

千木良尚志*，小池斗誌江*，長谷川篤司*，伊藤和雄*，和久本貞夫*，早川 徹**

*昭和大学歯学部第二歯科保存学教室

**日本大学松戸歯学部歯科理工学教室

$35 \% \mathrm{HEMA}$ 水溶液に希釈されたジカルボン酸また は，そのエステル構造物を含む市販及び試作の Self Etching Dentin Primerの効果を象牙質円柱窩洞内での 可視光線重合型コンポジットレジンのコントラクション ギャップの計測と象牙質平面に対する引つ張り接着強さ によって評価した。

試作した primer はすべて市販のリン酸エステル系ボ ンディング材と，また市販品のセルフエッチングタイプ の primer は付属のレジンモノマーを併用し, 全ての窩 洞および被着面には，市販の光重合型コンポジットレジ
ンを垻塞または接着させた。

その結果, HEMA にメタクリロキシエチルコハク酸 または,メタクリロキシエチルフタル酸を溶解した 2 種 類の試作 primer が，今回用いられたボンディイグ材の 象牙質に対する接着性を著明に向上させた。また，マレ イン酸を含む市販の primer は, 24 時間後の引つ張り接 着強さが $11.9 \pm 5.7 \mathrm{MPa}$ と高い值を示したが，コンポ ジットレジンと象牙質窩壁との適合性を改善することは できなかった。

\section{水中浸漬下におけるコンポジットレジンの圧縮クリープ}

平野 進，平沢 忠

鶴胃大学歯学部歯科理工学教室

コンポジットレジンの圧縮クリープを 4 種の異なる応 力 (圧縮応力 $0 \sim 3.5 \mathrm{~kg} / \mathrm{mm}^{2}$ ) で水中浸漬下で 500 時間
にわたり行なった。得られた 4 種のクリープ曲線から, 一定時間経過したときの各クリープひずみと圧縮応力と 